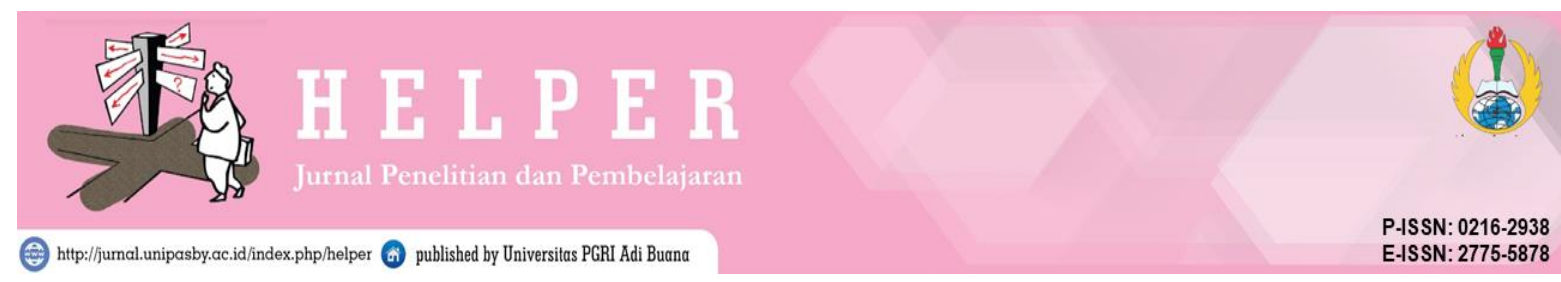

Vol. 38 No. 2 (2021)

\title{
PENGARUH PENGGUNAAN TEKNIK SELF-MANAGEMENT DALAM KONSELING KELOMPOK TERHADAP KEDISIPLINAN BELAJAR SISWA KELAS IX SMP NEGERI 24 SURABAYA
}

\author{
Adam Achmadi \\ ${ }^{1}$ Bimbingan dan Konseling, Universitas PGRI Adi Buana Surabaya, Surabaya, Indonesia \\ *Email: adamachmadi01@ gmailcom \\ Ayong Lianawati \\ ${ }^{2}$ Bimbingan dan Konseling, Universitas PGRI Adi Buana Surabaya, Surabaya, Indonesia \\ *Email: ayong@unipasby.ac.id
}

\begin{abstract}
Abstrak
Penelitian ini dilatar belakangi oleh tingkat kedisiplinan belajar siswa kelas IX yang rendah di masa pandemi covid-19 yang disebabkan karena faktor internal dan faktor eksternal. Tujuan penelitian ini adalah untuk mengetahui pengaruh penggunaan layanan konseling kelompok dengan teknik self management terhadap kedisiplinan belajar siswa kelas IX SMP Negeri 24 Surabaya. Penelitian ini menggunakan pendekatan kuantitatif dengan jenis penelitian pra eksperimen menggunakan desain penelitian one group pretest-posttest design. Populasi penelitian ini ialah siswa kelas IX A SMP Negeri 24 Surabaya terdiri atas 40 orang dan pengambilan sampel penilitian ini menggunakan teknik purposive sampling dan sampel penelitian berjumlah 10 orang. Metode pengumpulan data menggunakan observasi dan kuisioner kedisiplinan belajar siswa yang dikembangkan dari blue print kedisiplinan belajar siswa. Metode analisis data menggunakan uji wilcoxon pada SPSS versi 26.0. Hasil penelitian ini menunjukkan peningkatan kedisiplinan belajar dari hasil Asymp.Sig SPSS sebesar 0,005 yang kurang dari taraf signifikan $(0,05)$ dapat diartikan bahwa adanya pengaruh penggunaan teknik self management dalam meningkatkan kedisiplinan belajar siswa.
\end{abstract}

Kata Kunci: Teknik Self Management, Konseling Kelompok, Kedisiplinan Belajar

\begin{abstract}
Abstact
This research was motivated by a low level of discipline in learning of grade IX students during the covid-19 pandemic caused by internal and external factors. The purpose of this research is to find out the influence of the use of group counseling services with self management techniques on the discipline of learning students of grade IX SMP Negeri 24 Surabaya. This study uses quantitative approach with preexperimental research type using one group pretest-posttest design research design. The population of this study is grade IX A students of SMP Negeri 24 Surabaya consisting of 40 people and sampling this research using purposive sampling techniques and research samples numbering 10 people. Data collection method using observation and questionnaire of student learning discipline developed from blue print student learning discipline. The data analysis method uses wilcoxon test on SPSS version 26.0. The results of this study showed an increase in learning discipline from the results of Asymp.Sig SPSS of 0.005 which is less than a
\end{abstract}


Pengaruh Penggunaan Teknik Self-Management Dalam Konseling Kelompok Terhadap Kedisiplinan Belajar

significant level $(0.05)$ can be interpreted that the influence of the use of self management techniques in improving student learning discipline.

Keywords: Self-Management Techniques, Group Counseling, Learning Discipline

\section{PENDAHULUAN}

Masa pandemi pada beberapa bulan terakhir ini mengakibatkan pada dunia pendidikan terlihat kacau dikarenakan adanya beberapa sistem pembelajaran yang awalnya berjalan normal dengan pembelajaran tatap muka sekarang digantikan dengan sistem pembelajaran non tatap muka selama wabah pandemi yang menjangkit di seluruh belahan bumi. Masa sekarang ialah masa yang sulit yang dihadapi oleh tenaga pengajar dan peserta didik, karena pada masa pandemi banyak beban yang diserahkan kepada para pengajar dan peserta didik, di mana mereka mau tidak mau harus memiliki kegiatan ekstra dalam melakukan kegiatan belajar dan mengajar. Kegiatan belajar dan mengajar kini dilakukan dengan pembelajaran jarak jauh atau sering kita sebut dengan pembelajaran dalam jaringan atau daring. Kegiatan penelitian ini lebih dikhususkan peneliti untuk meneliti kegiatan siswa kelas IX di SMP Negeri 24 Surabaya. Kegiatan pembelajaran daring kali ini memfokuskan kepada peserta didik kelas IX.

Dampak negatif virus covid-19 menimbulkan berbagai fenomena yang sering kita jumpai di dalam kehidupan sehari-hari kita seperti halnya kita sebagai peserta didik yang sering merasakan kejenuhan, kemalasan, dan sering menunda tugas, serta enggan dalam mengikuti pembelajaran dalam jaringan yang setiap pagi hingga siang. Masa pandemi seperti sekarang juga mengakibatkan fenomena pengangguran massal karena pihak lapangan pekerjaan juga tidak mau menerima risiko pengeluaran yang begitu banyak. Sehingga banyak bermunculan fenomena seperti kesenjangan sosial. Akan tetapi dalam penelitian kali ini, peneliti akan membahas fenomena dari dampak melandanya wabah virus covid-19 yang terjadi pada sektor pendidikan di lingkup sekolah menengah pertama. Fenomena tersebut antara lain penurunan kedisiplinan belajar siswa yang mengakibatkan nilai dari setiap akademis siswa menurun, dan juga sikap akan motivasi belajar siswa juga cenderung menurun selama masa pandemi.

Menurut Zainal (dalam Suharya, dkk, 2018) Berpendapat disiplin belajar ialah langkah atau upaya yang perlu, guru, kepala sekolah, orang tua, dan murid ikuti untuk mengembangkan suatu keberhasilan tingkah laku siswa baik akademik maupun sosial yang dilakukan berdasarkan serangkain proses atau peristiwa yang ditaati, dipatuhi, dan diterapkan dalam proses belajar, oleh sebab itu perlu mendapatkan perhatian khusus dari semua pihak yang 
berada di lingkup sekolah dan sekitarnya. Menurut Amri, S (2013) Disiplin belajar memiliki arti kepatuhan, ketaatan, pengendalian, dan pengekangan dorongan terhadap suatu peraturan dan pengendalian dalam suasana kegiatan belajar yang memiliki tujuan untuk memiliki perilaku yang tertib atau disiplin pada aturan proses belajar supaya nantinya dapat menunjukkan hasil bahwa dirinya telah berperilaku tertib dalam lingkup kegiatan pendidikan.

Pentingnya penelitian kedisiplinan belajar didasarkan karena pada permasalahan yang timbul di kelas IX SMP Negeri 24 Surabaya banyak siswa yang sering tidak mengerjakan tugas dan sering tidak mengikuti pembelajaran daring sehingga memengaruhi nilai akademik dan sikap siswa saat pelajaran berlangsung. Penelitian dengan kedisiplinan belajar yang berbantuan teknik self managemnt dalam konseling kelompok ini diberikan kepada siswa kelas IX karena dengan memberikan teknik self management untuk melatih siswa menjadi disiplin dalam belajarnya yang dimana dapat meningkatkan kecakapan dalam hal belajar siswa. Didukung dari penelitian Juliandi, Y. (2014) mengemukakan bahwasanya dengan berdisiplin akan membuat siswa memiliki kecapakan dalam belajar yang baik, serta berdisiplin merupaka proses kearah pembentukan kepribadian yang baik.

Menurut Rachman (dalam Kristiyanti, 2016) Menyatakan pentingnya disiplin bagi siswa, yakni a. Memberi dukungan terciptanya perilaku yang tidak menyimpang dan membantu siswa menyesuaikan diri dengan tuntutan lingkungan, b. serta menyelesaikan tuntutan yang ingin ditunjukkan siswa terhadap lingkungannya, c. menjauhkan siswa melakukan hal-hal yang dilarang sekolah, mendorong siswa melakukan hal-hal yang baik dan benar, d. siswa belajar hidup dengan kebiasaan-kebiasaan yang baik, positif dan bermanfaat bagi diri sendiri dan lingkungannya, e. kebiasaan baik ini juga dapat menyebabkan ketenangan jiwa dan lingkungannya seseorang. Budi pekerti yang baik akan dimiliki siswa dengan latihan berdisiplin.

Faktor-faktor yang mempengaruhi disiplin belajar menurut Suradi. (2011). Terdapat dua faktor yang mempengaruhi terbentuknya sikap disiplin belajar pada seseorang individu yakni faktor dari dalam dan faktor dari luar individu. Faktor dari dalam antara lain meliputi ranah kognitif, minat, dan motivasi. Faktor dari luar yakni faktor yang berasal dari lingkungan keluarga, masyarakat, dan sekolah. Faktor kedisiplinan belajar yang dikemukakan oleh Yuliantika. (2017) Faktor disiplin belajar yaitu faktor keadaan psikis, fisik, kebiasaan keluarga, penerapan tata tertib sekolah, serta kondisi lingkungan masyarakat. Disiplin sangat penting bagi semua peserta didik, karena dengan sikap disiplin nantinya akan menjadikan peserta didik 
yang lebih baik lagi dan lebih mengarahkan mereka untuk memiliki kepribadian yang lebih positif lagi. Sikap disiplin yang terjadi dalam diri seseorang juga menandakan bahwa dirinya telah mampu mengendalikan dan mengelola waktu dalam dirinya agar lebih baik lagi.

Disiplin belajar siswa dapat terwujud dengan baik dan benar apabila siswa tersebut memiliki sistem pengelolaan diri yang baik. Pengelolaan diri dalam layanan konseling yang terutama dalam proses konseling kelompok di mana proses tersebut bersifat pencegahan kepada siswa yang memang sangat membutuhkan proses tersebut, proses tersebut digunakan untuk membantu mereka dalam mengerjakan tugas dan menyelesaikan kegiatan belajar maupun kegiatan di luar belajar yang dimiliki siswa, serta mengarahkan diri mereka agar menjadi pribadi yang lebih baik lagi.

Sedanayasa, G (2014). Self management adalah kemampuan seorang individu dalam mengelola pola perilaku guna untuk memperoleh perilaku aktivitas baru yang lebih efektif dan produktif. Pengelolaan diri dalam bimbingan konseling memiliki pengertian strategi perubahan tingkah laku atau kebiasaan dengan pengaturan dan pemantauan yang dilakukan oleh konseli itu sendiri, pengendalian rangsangan atau penghargaan terhadap diri sendiri. Menurut Komalasari (dalam Isnaini, 2014). Strategi pengelolaan diri dalam konseling kelompok ditujukan guna untuk mencegah terjadinya ketidakdisplinan belajar peserta didik yang di mana memang menjadi solusi dan strategi yang tepat untuk melakukan pencegahan tersebut, karena dengan penggunaan strategi ini juga didukung dan dikuatkan oleh penelitian sebelumnya bahwa penggunaan strategi self management mampu meningkatkan kedisiplinan belajar peserta didik.

Dampak positif yang ditimbulkan setelah diberikan perlakuan teknik self management dalam konseling kelompok adanya kemajuan dan peningkatan dalam disiplin belajar seperti halnya adanya kemauan siswa mengikuti pekatihan dan mengerjakan tugas, serta siswa juga mulai belajar malam hari dan mengikuti pembelajaran daring. Sejalan dari pemaparan tersebut juga didukung dari hasil penelitian Fajrani, dkk (2016) menjelaskan ada pengaruh penggunaan teknik self management dalam peningkatan kedisiplinan belajar seperti halnya mengerjakan tugas, mau mengikuti pembelajaran, dan sudah menata kegiatan belajar pada malam hari, serta tidak pernah terlambat masuk. Menurut Komalasari (dalam Fajrina, dkk, 2016) menjelaskan dampak positif teknik self management terhadap kedisiplinan belajar siswa memberikan dampak yang sangat baik yakni dengan merubah perilaku yang mereka lakukan tanpa paksaan orang lain. 
Pengaruh Penggunaan Teknik Self-Management Dalam Konseling Kelompok Terhadap Kedisiplinan Belajar

Dampak yang terjadi jika siswa tidak meningkatkan kedisiplinan belajar maka siswa tersebut tidak mampu mengontrol dirinya dan tidak mempunyai kesadaran dalam dirinya sehingga malas dalam belajar kemudian tidak mengerjakan tugas, sehingga hal tersebut dapat berpengaruh terhadap prestasi belajarnya. Menurut (Widosari, 2014) perilaku ketidakdisiplinan siswa akan berdampak pada prestasi belajar maupun mental siswa, sehingga mengakibatkan kurang berkembang dalam prestasi belajar. Dapat disimpulkan bahwa dampak yang terjadi jika siswa tidak melakukan kedisiplinan dalam belajar, siswa akan ketinggalan pelajaran yang berdampak pada prestasi belajar.

\section{METODE}

Penelitian ini menggunakan rancangan one group pre-test post-test design yang merupakan kelompok penelitiian pra-eksperimental Sugiyono (dalam Nindi, L. 2020) Rancangan penelitian ini diuraikan pada gambar di bawah ini.

\section{Rancangan Penelitian One Group Pre-test Post-test Design}

$$
\mathrm{O}_{1} \quad \mathrm{X} \quad \mathrm{O}_{2}
$$

O1: Pengukuran variabel terikat yaitu kediplinan belajar siswa dengan menggunakan skala pengukuran sebelum sekelompok subjek penelitian diberikan layanan konseling kelompok dengan menggunakan strategi self management.

O2: Pengukuran variabel terikat yaitu kedisiplinan belajar siswa dengan menggunakan skala pengukuran setelah sekelompok subjek penelitian diberikan layanan konseling kelompok dengan menggunakan strategi self management.

$\mathrm{X}$ : yaitu pemberian layanan konseling kelompok dengan menggunakan teknik self management.

\section{HASIL PENELITIAN DAN PEMBAHASAN}

\section{Hasil Penelitian}

Hasil penelitian didapatkan setelah peneliti menyebarkan soal pre-test kepada para siswa. Setelah soal tersebut dibagikan dan dikerjakan maka hasil dari pre-test tersebut yang nantinya akan menentukan berapa jumlah subyek yang akan diteliti. Hasil dari nilai pre-test tersebut terdapat ada 4 orang yang mempunyai hasil rendah dan 6 orang mempunyai hasil sangat rendah, pada tabel dan grafik di bawah ini. 
Tabel 1. Hasil Pre-test Kelas IX A

\begin{tabular}{ccc}
\hline Responden & Pre-Test & Kategori \\
\hline Wsb & 104 & Rendah \\
Dsak & 86 & Sangat Rendah \\
Acpa & 105 & Rendah \\
Ribs & 101 & Rendah \\
Raw & 83 & Sangat Rendah \\
Akea & 97 & Sangat Rendah \\
Rnpw & 99 & Rendah \\
Amp & 84 & Sangat Rendah \\
Abz & 86 & Sangat Rendah \\
Raz & 85 & Sangat Rendah
\end{tabular}

Grafik 1. Hasil Pre-test Kelas IX A

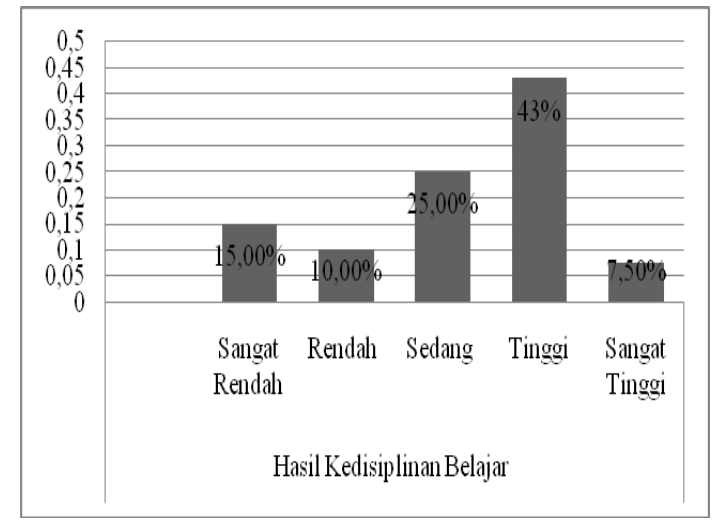

Hasil pre-test yang telah diperoleh adalah 10 orang siswa yang mempunyai nilai kedisiplinan belajar sangat rendah dan rendah, kemudian dianlisa oleh peneliti maka setelah itu perlu diadakannya proses konseling kelompok guna membantu para siswa yang memiliki nilai kedisiplinan belajar rendah agar menjadi meningkat melalui pendekatan konseling kelompk dengan menggunakan teknik self management untuk memudahkan para siswa membuat jadwal keseharian memanajemen diri agar tidak menyepelekan waktu belajar di rumah serta mengatur hidupnya agar lebih baik lagi.

Konseling kelompok dengan teknik self management yang diberikan kepada para siswa memiliki beberapa tahapan. Tahapan konseling kelompok dengan teknik self management adalah sebagai berikut.Pertemuan utama seorang konselor ialah menciptakan suasana dan hubungan yang baik dengan para konseli. Pertemuan kedua konselor menegaskan kembali kegiatan konseling kelompok dan mulai bertanya menegnai kesiapan konseli dalam mengikuti konseling, serta dimulainya diskusi antar koselor dan konseli. Pertemuan ketiga adalah tahapan kerja dari serag konselor yang mulai bertanya kepada konseli untuk menggali informasi 
Pengaruh Penggunaan Teknik Self-Management Dalam Konseling Kelompok Terhadap Kedisiplinan Belajar Siswa Kelas IX SMP Negeri 24 Surabaya

mendlam tentang masalah yang dihadapi konseli dan memberikan strategi self management kepada konseli semuanya. Keempat ialah pertemuan yang membahasa bagaimana pemecahan suatu masalah yang dihadapi konseli dan mengulang kembali hal yang perlu dilakukan oleh konseli. Terakhir merupakan pertemuan kelima ialah kegiatan konseling pada tahap akhir yang dilakukan dengan memberikan penguatan dan pengahapusan tingkah laku konseli serta pengungkapan kesan dan pesan selama proses konseling.

Hasil konseling kelompok menggunakan teknik self management terhadap kedisiplinan belajar siswa kelas IX A di SMP Negeri 24 Surabaya terbukti meningkat dari semula yang memiliki nilai sangat rendah dan rendah kini menjadi lebih baik yakni tertera pada tabel di bawah ini.

\begin{tabular}{|c|c|c|c|}
\hline Rspndn & Pre-Test & Posttest & Kategori \\
\hline Wsb & 104 & 152 & Sangat Tinggi \\
\hline Dsak & 86 & 147 & Tinggi \\
\hline Acpa & 105 & 149 & Tinggi \\
\hline Ribs & 101 & 155 & Sangat Tinggi \\
\hline Raw & 83 & 150 & Sangat Tinggi \\
\hline Akea & 97 & 153 & Sangat Tinggi \\
\hline Rnpw & 99 & 157 & Sangat Tinggi \\
\hline Amp & 84 & 143 & Tinggi \\
\hline Abz & 86 & 145 & Tinggi \\
\hline Raz & 85 & 141 & Tinggi \\
\hline
\end{tabular}

Tabel 2. Hasil Perbandingan Pre-test dan Post-test Kelas IX A

Tabel di atas menunjukkaan sebuah hasil penerapan konseling kelompok dengan teknik self management pada siswa yang memiliki nilai kedisiplinan belajar yang rendah mengaami peningkatan yang sangat siginifikan.peningkatan tersebut terjadi karena adanya sitem manajemen diri yang baik pada kegiatan di rumah dan belajarnya yang dilakukan dengan membuat jadwal kegiatan yang baik guna melatih siswa untuk membuat tingkah laku yang berbena dalam belajarnya.

\section{Pembahasan}

Pengujian hipotesis penelitian ini menggunakan teknik analisis data uji wilcoxon, pada tabel 3 hasil penelitian menunjukkan hasil peningkatan nilai possitve rank yang dimana sampel yang diberi layanan mengalami peningkatan dari 10 orang kelas pretest, serta pada kolom negative rank dari hasil negative rank memiliki hasil jumlah sampel 0 rank, maka dalam 
Pengaruh Penggunaan Teknik Self-Management Dalam Konseling Kelompok Terhadap Kedisiplinan Belajar Siswa Kelas IX SMP Negeri 24 Surabaya

pemberian penelitian ini tidak mengalami penurunan, sedangkan nilai rata-rata peningkatannya sebesar 5,50, selanjutnya nilai ties (kesamaan nilai) antara hasil pretest dan posttest memiliki nilai sebesar 0 yang artinya tidak memiliki nilai yang sama pada hasil pretest dan posttest.

\begin{tabular}{|c|c|c|c|c|}
\hline \multicolumn{5}{|c|}{ Ranks } \\
\hline & & $\mathrm{N}$ & Mean Rank & Sum of Ranks \\
\hline \multirow[t]{4}{*}{ post-pre } & Negative Ranks & $0^{\mathrm{a}}$ & ,00 & ,00 \\
\hline & Positive Ranks & $10^{\mathrm{b}}$ & 5,50 & 55,00 \\
\hline & Ties & $0^{\mathrm{c}}$ & & \\
\hline & Total & 10 & & \\
\hline \multicolumn{5}{|c|}{ a. post $<$ pre } \\
\hline \multicolumn{5}{|c|}{ b. post > pre } \\
\hline c. post $=p$ & & & & \\
\hline
\end{tabular}

Tabel 3. Ranks pada SPSS for Windows versi 26.0

\begin{tabular}{|l|r|}
\hline \multicolumn{2}{|c|}{ Test Statistics $^{\boldsymbol{a}}$} \\
\hline & $\begin{array}{c}\text { post - } \\
\text { pre }\end{array}$ \\
\hline$Z$ & $-2,807^{\mathrm{b}}$ \\
\hline Asymp. Sig. (2-tailed) &, 005 \\
\hline \multicolumn{2}{|c|}{ a. Wilcoxon Signed Ranks Test } \\
\hline \multicolumn{2}{|c|}{ b. Based on negative ranks. } \\
\hline
\end{tabular}

Tabel 4 Test Statistisc

Hasil statistik pada tabel di atas dapat diketahui bahwa hasil Asymp. Sig (2 tailed) sebesar 0,005. Nilai 0,005 tersebut kurang dari taraf signifikan $(\leq 0,05)$, maka dapat disimpulkan bahwa hipotesa penelitian ini diterima, sehingga dapat dikatakan adanya pengaruh penggunaan teknik self management dalam peningkatan kedisiplinan belajar siswa kelas IX A di SMP Negeri 24 Surabaya.

Hal ini juga sejalan dengan hasil penelitian yang dilakukan di SMA Negeri 5 Banda Aceh pada siswa kelas XI dan XII bahwasannya siswa yang mendapatkan perlakuan teknik self management dalam layanan konseling kelompok terhadap peningkatan kedisiplinan belajar siswa mengalami peningkatan dari aspek peningkatan belajar seperti halnya kemauan siswa untuk mengikuti kegiatan pembelajaran, mengerjakan pekerjaan rumah, menata jadwal kegaiatan belajar malam. 
Pengaruh Penggunaan Teknik Self-Management Dalam Konseling Kelompok Terhadap Kedisiplinan Belajar

\section{KESIMPULAN}

Penelitian yang dilakukan di SMP Negeri 24 Surabaya dapat disimpulkan bahwa terdapat pengaruh penggunaan teknik self management dalam konseling kelompok terhadap kedisiplinan belajar siswa kelas IX A. Pengaruh kedisiplinan belajar pada masa pandemi ini disebabkan oleh beberapa faktor di antaranya yaitu faktor yang berasal dari dalam individu seperti minat dan bakat dalam proses belajar di masa pandemi dan faktor dari luar individu seperti faktor ekonomi keluarga yang tidak mendukung untuk menunjang kebutuhan sekolah peserta didik, faktor luar lainnya yakni seperti pemusatan perhatian orang tua yang kurang dalam mengarahkan dan mendidik anak di masa pandemi dan faktor dari pergaulan teman sebaya ataupun faktor lingkungan yang di mana membuat para peserta didik lupa akan waktu belajar dan sibuk untuk bermain bersama temannya..

Berdasarkan hasil dari penelitian dengan menggunakan uji wilcoxon didapatkan hasil test statistic yang diketahui bahwa hasil Asymp. Sig (2 tailed) sebesar 0,005. Nilai 0,005 tersebut kurang dari taraf signifikan $(\leq 0,05)$, serta menghasilkan rata-rata peningkatan sebesar $5,50 \%$. Yang awal kelas pre-test kategori rendah menjadi kategori tinggi pada hasil post-test..

\section{DAFTAR PUSTAKA}

Amri, S. 2013. Pengembangan \& Model Pembelajaran . Jakarta: PT. Prestasi Pusta Karya.

Azwar, S. 2017. Penyusunan Skala Psikologi Edisi 2. Yogyakarta: Pustaka Pelajar.

Fajrani. 2016. Self Management untuk Meningkatkan Kedisiplinan Belajar Siswa: Studi Kasus di SMA Negeri 5 Banda Aceh. Jurnal Pencerahan, 10, 95-102.

Furqon. 2014. Statistika Penerapan untuk Penelitian. Bandung : Alfabeta.

Isnaini, F. 2014. Strategi Self Management untuk Meningkatkan Kedisiplinan Belajar. Surakarta: Universitas Muhammadiyah Surakarta Press.

Juliandi, Y. 2014. Pengaruh Disiplin Belajar Terhadap Hasil Belajar Siswa pada Mata Pelajaran Ekonomi SMAS Taman Mulia. 3-17.

Kristiyanti. 2016. Hubungan Disiplin Belajar dengan Hasil Belajar PKN Siswa kelas IV SD Segugus Diponegoro Kecamatan Banyu Biru Kabupaten Semarang. Semarang: Universitas Negeri Semarang.

Nindi, L. 2020. Panduan Praktis Metode Penelitian Kuantitatif dalam Ilmu Sosial . Jakarta: Adhi Sarana Nusantara Press.

Sedanayasa, G. 2014. Pengembangan Pribadi Konselor. Yogyakarta: Graha Ilmu.

Suharya. 2018. Hubungan Antara Disiplin Belajar dengan Hasil Belajar Siswa pada Mata Pelajaran Matematika. Jurnal Prosiding Seminar Nasional Pendidikan, 17-24. 
Pengaruh Penggunaan Teknik Self-Management Dalam Konseling Kelompok Terhadap Kedisiplinan Belajar Siswa Kelas IX SMP Negeri 24 Surabaya

P-ISSN: 0216-2938

E-ISSN: $2775-5878$

Widosari. 2014. Upaya Meningkatkan Kedisiplinan Melalui Layanan Bimbingan Kelompok dengan Teknik Behavior pada Siswa. Jurnal Ilmiah Pendidikan Bimbingan dan Konseling, 56-62. 